\title{
China-IMF Collaboration: Toward the Leadership in Global Monetary Governance
}

\author{
Jue Wang ${ }^{1}$ (i)
}

Received: 12 September 2017/ Accepted: 15 September 2017/Published online: 4 October 2017

(C) The Author(s) 2017. This article is an open access publication

\begin{abstract}
This paper analyses China's collaboration with the IMF in various programmes, including China's participation in IMF technical assistance programmes, IMF country surveillance for China, China's attempt to weaken the US dominance in the international monetary system through the IMF, and the RMB's entry to the SDR basket. The results of these collaboration activities reflect the extent to which the IMF assists China in pursuing leadership in global governance of monetary policies. The paper raises two key points. First, it highlights the impact of Chinese actors' interests and objectives regarding China's domestic economic development and outward expansion on their government's interaction with international organizations. Second, it argues that the result of China-IMF collaboration is determined by two conditions (a) the compatibility between Chinese and IMF interests and objectives regarding key economic and political issues, and (b) China's relative role in the IMF's institutional governance in comparison with the Fund's other member states.
\end{abstract}

Keywords China · China-IMF collaboration · Institutional decision-making power $\cdot$ Global monetary governance $\cdot$ International monetary reforms

\section{Introduction}

The 2008 global financial crisis severely destabilized the US-dominated international financial regime and its repercussions have continued to (re-) shape the world economic structure until present. Although different markets and governments have

Jue Wang

j.wang.18@hum.leidenuniv.nl

1 Leiden Institute for Area Studies, Leiden University, Arsenaalstraat 1, 2311 CT Leiden, The Netherlands 
implemented numerous compensating instruments, including a variety of institutional and macroeconomic policy changes, the international financial system will not return to its pre-crisis state. On the contrary, these changes have gradually led to a new global financial governance structure with a number of resurrected or novel components. Among all, this paper delves into two inter-related elements: the IMF's attempt to return to the front line of global financial governance and China's pursuit of leadership in the same realm.

Due to its highly restrained external trade and investment relations, China was absent from the international financial system until the 1980s. As a latecomer, it has, however, gradually integrated into the existing international financial architecture, with the assistance of international financial institutions (IFIs) such as the IMF, and become an increasingly active member of global governance of monetary policies. Before the 2008 financial crisis, China had participated in various IMF programmes to get access to advanced methods and techniques of financial governance that met the international standards and useful feedback for its domestic economic development. After the crisis burst, China and the IMF acknowledged further each other's increasing importance in the post-crisis global monetary governance and strengthened their collaboration.

For example, under the pressure of 'US dollar trap', China called the IMF for taking the initiative in shifting the focus of international monetary system (IMS) away from the US, while seeking leadership in the reformed system. Meanwhile, China actively advocated strengthening the IMF's Special Drawing Rights (SDR) and letting the Renminbi (RMB) join the SDR basket to reinforce the RMB's role in the IMS. These examples of China-IMF collaboration show the recent developments in China's relationship with international economic organizations, referring to the evolution from merely China learning from the international organizations (IOs) to China collaborating with the IOs for greater influence in global governance.

China-IMF collaboration has generated various results, with some fulfilling both China and the IMF's needs whereas others leading to disputes between the two. Studying the causes of such variations helps us understand the progress of China's pursuit of leadership in global monetary governance through the IMF. Hence, this paper will focus on the determinants of the result of China-IMF collaboration based on a number of case studies, including China's participation in IMF technical assistance (TA) programmes, IMF country surveillance for China, China's attempt to weaken the US dominance in the IMS through the IMF, and the RMB's entry to the SDR basket. The paper raises two key points. First, it highlights the impact of Chinese actors' interests and objectives regarding China's domestic economic development and outward expansion on their government's interaction with IOs. Second, it argues that the result of China-IMF collaboration is determined by two conditions (a) the compatibility between Chinese and IMF interests and objectives regarding key economic and political issues, and (b) China's relative role in the IMF's institutional governance in comparison with the Fund's other member states.

The next sections are arranged as follows. Section 2 briefly discusses a number of crucial concerns in the studies of China-IO relationship as well as explains the research focus in this paper. Section 3 assesses China's relative role in the IMF's institutional governance as a determinant of the result of China-IMF collaboration. 
Section 4 scrutinizes the cases of China-IMF collaboration according to the IMF's two main functions- 'International Organization specialization' and 'agenda setting power' - and examines the determinants of collaboration results, followed by the conclusion in Sect. 5.

\section{China and the IMF: Collaborating Toward Greater Governance Role}

Unlike the influential financial powers in the western world, Beijing was absent from the initial designing and facilitating of post-war international monetary system. Neither did it catch the early train of economic globalization, and thus reinforcing its financial strength in the early post-Bretton Woods era. As a latecomer, Beijing, however, has gradually integrated into the existing international financial architecture since the early 1980s, with the assistance of IFIs such as the IMF, and become an important member of global governance of monetary policies. The Chinese government collaborated with the IMF in various forms, which consequently generated diverse results. These results of collaboration, whether benefiting both sides equally or satisfying one side more than the other, reflect China's dynamic role in global monetary governance.

\subsection{China: A Rising Power in Global Financial Governance}

In the literature of China's relationship with IOs, scholars often discuss how China can be 'socialized' (or not) to be a responsible status quo actor in global governance arenas, whether China plays by the existing international rules, wants to modify them, or seeks to radically change them and establish new institutions, rules and norms (Acharya 2011; Han 2007; Lynch 2006; Johnston 2008; Kent 2002). The socialization approach explains well how China has learned internationally standardized practices from IOs. Johnston's (2008) three 'microprocesses' of socialization-mimicking, social influence and persuasion-detailed how China was engaged in the international security regime. These 'microprocesses' could also be applied partially to China's early engagement with the IMF, indicating how China learned a variety of data processing and policy making methods from the IMF, and that China gradually liberalized its financial regime under the IMF's influence (Ferdinand and Wang 2013).

However, existing studies following the socialization logic do not explain why China has become increasingly intractable facing the IMF on certain issues. Socialization theories normally expect the states to be further 'socialized' into accepting the existing norms of the IOs, thanks to the mutual sympathy and understanding established between them over time. However, after two decades of peaceful collaboration between China and the IMF, a number of issues have caused heated tension between the two in the new millennium. For instance, they had serious disputes on whether or not the Chinese government manipulated the RMB exchange rate in the late 2000s. China also protested with strong actions against the IMF's western-dominated governance structure and its 'biased surveillance focuses' against China and other emerging economies. 
It is largely because existing studies failed to trace the changing interests and objectives of Chinese actors. As the Chinese economy grew into different stages and its influence in the international affairs strengthened, China's interests and objectives regarding its domestic economic development and outward expansion have also evolved. The socialization approach, which often regards states as passive receivers of static norms, fails to capture the dynamic changes in the Chinese actors' interests and objectives that actively shape Beijing's interaction with IOs. In its collaboration with the IMF, especially in the early periods, the Chinese government has hoped to learn advanced methods and techniques of financial governance that meet the international standards; it has also hoped to gain feedback for its own economic policies and useful information about the economic development of other countries. Nevertheless, as China became more assertive about its own political and economic regimes, it has also developed stronger resistance against the IMF advice that is perceived as intrusive or harmful for China's own development. For example, the IMF's advice on evaluating the RMB was conceived as one. Meanwhile, China's aspiration to enlarge its influence in the IMS has surged, and sometimes going beyond the IMF's capacity. These dynamics in China's interests and objectives largely reflect as well as shape China's political identities and economic norms, two core elements that determine a state's actions in international affairs from a social constructivist perspective. Hence, only by taking into consideration China's dynamic interests and objectives regarding key economic and political issues, the socialization approach can capture a comprehensive and updated picture of China's actions in international financial affairs.

On the other hand, states' interests and objectives are the focus of rational choice approaches to studying state-IO relationship. For instance, the Principal-agent theory argues that states hire IOs to perform some functions to achieve the objectives of the former (Nielson and Tierney 2003; Hawkins et al. 2006). This logic, combined with the international institutionalist interpretation of states' reliance on IOs to solve transnational issues, largely explains why states have become more involved in existing IOs or endeavoured to establish new ones in the past decades. Following this logic, the strong influences of the US political interests in the IMF's lending decisions are particularly evident (Thacker 1999; Broz and Hawes 2006). This logic is, however, rarely applied to the interactions between emerging market countries and IOs. In the realm of global financial governance, the emerging economies lacked any effective influence in IFIs, let alone the possibility of instigating IFIs to undertake certain policy, until the more recent years. In particular, when a series of regional and global financial crises took place in the $80 \mathrm{~s}$ and 90s, some emerging economies were forced to submit to the political conditionalities of the IMF and other regional and international financial institutions to receive loans.

The balance between strong IFIs and weak emerging and developing economies was, however, broken by the 2008 global financial crisis. China survived the crisis as a new leader of the international financial system, whereas the former leaders, namely the US and other advanced western economies remained deeply mired. China requested larger decision-making power in the traditional IFIs such as the IMF and the World Bank, and (co-) established new ones such as the New 
Development Bank (NDB) and the Asian Infrastructure Investment Bank (AIIB). In the realm of monetary governance, China encouraged the IMF to take the initiative in shifting the focus of IMS away from the US, while actively seeking leadership in the reformed system via a series of collaboration with the Fund. A good example of such collaboration would be the RMB's entry into the SDR basket in 2016. Just like the US and other western developed economies, China has also made decisions upon collaborating with IFIs based on its own interests and objectives regarding key economic and political issues. Moreover, as an emerging power in the international financial system that it did not build from the beginning, China relies even more on the existing IOs for pursuing leadership in the system. The abovementioned case of China-IMF collaboration showed this point, and it will be elaborated later in the paper. Therefore, clarifying China's interests and objectives not only complements the socialization approach by adding more dynamic elements to the question but also updates the rational choice approach to studying the state-IO relationship by including a key rising power, namely China's role in global financial governance.

\subsection{Analyzing China-IMF Collaboration}

China's interests in domestic economic development and its objectives in pursuing greater influence in global financial governance do not stand as the sole determinants of China's collaboration with the IMF. The latter also largely depends on what the IMF could offer to help China fulfil its interests and objectives. The study of China-IMF collaboration in this paper relates China's interests and objectives to the IMF's functions, and assesses the extent to which the latter meet the requests of the former. This rational choice approach to analyzing the ChinaIMF relationship accords with China's enhanced voices, growing interests, and pragmatic manners in international affairs. Meanwhile, the IMF also has distinct interests and objectives that guide its interactions with China.

The IMF's essential objective is to maintain its authority and autonomy in global financial governance by providing its member states with useful loans, training, and advice. Although the IMF attempts to stay neutral, its organizational culture, like that of the World Bank, is often considered to be a "Washington-centric approval culture' that is guided by 'neoliberal economic theory' and characterized by 'a technocratic approach to problems' (Nielson et al. 2006: 109; Park and Vetterlein 2010). This, however, does not mean that the IMF holds on to the neoliberal economic ideology to the same extent in all the policy practices.

When China's interests and objectives converge with those of the IMF, its collaboration with the IMF tends to generate the result that fulfils China's needs. If China and the IMF have diverging interests and objectives, the result of their collaboration is less pleasant. Another important determinant of the result of ChinaIMF collaboration is China's role in the IMF's institutional governance, which will be explained briefly in the next section. China's institutional role in the IMF depends on its relative influence in the Fund's decision-making process in comparison with other member states. The larger a state's relative decision-making power is, the more capable it is to convince the IMF to make a policy decision that matches the state's own interests, and vice versa. Hence, smooth collaboration 
between China and the IMF has two conditions: matching interests and objectives between China and the IMF and a strong Chinese position in the IMF's institutional governance.

\section{China in the IMF's Institutional Governance}

A member state's decision making power in the IMF is divided into two categories: formal and informal, referring to the state's relative position in the IMF's formal and informal governance structures, respectively.

\subsection{Formal Decision-Making Power}

A state's formal decision-making power is determined by its relative voting share in the Executive Board (EB), the IMF's central governance body. The EB is responsible for conducting the day-to-day business of the IMF. The EB includes 24 executive directors (EDs), who are either appointed or elected among the representatives of all member states. Most of the EDs represent a constituency of several member states, whereas 8 EDs represent a single country, the US, Japan, China, Germany, France, the UK, Russia and Saudi Arabia, respectively. They are also the Fund's 8 largest member states by voting share. ${ }^{1}$

China is currently the IMF's third largest member by voting share. This is a recent result of China's decade long struggle for larger voices in the IMF's formal governance. Before that, China, along with other emerging economies, had been under-represented for a long time. Thus, China joined the campaign for IMF governance reforms that focused on increasing the emerging and developing economies' voices in the Fund. China has benefited from three most recent IMF governance reforms, launched in 2006, 2008 and 2010, respectively. Among all, the 2010 reform represented the largest power shift in favour of the Fund's emerging and developing economy members in the history according to the then IMF Manager Director Dominique Strauss-Kahn (IMF 2010a). The 2010 reform nevertheless only became effective in January 2016, after a severe delay. It was mostly because the US Congress did not ratify the reform in time, without which the reform could not be implemented according to IMF regulations. The Chinese authorities repeatedly urged the IMF to implement the reform, but the IMF could not do much without the US approval.

After the 2010 reform was ratified, China's voting share among all IMF member states increased from 3.8 to $6.1 \%$, making China the IMF's third largest member after the US and Japan. This change marked China's significant achievement in winning larger formal decision-making power in the IMF. It, however, did not fundamentally alter the IMF's Western-dominated governance structure. Despite the

\footnotetext{
${ }^{1}$ The EB makes decisions upon all the proposals, whether to pass or reject them, mostly by consensuses. If a consensus could not be reached, the EDs would vote to generate a decision, but they rarely need to do so. When the EDs have contradictory preferences, they must go through several rounds of negotiations to reach a decision. Such decisions often require the less influential EDs to compromise in order to satisfy the powerful EDs' preferences.
} 
slight decline in the US voting share from 16.7 to $16.5 \%$, the US continued to hold a veto right in the EB's formal decision-making process. With the veto power the US can block any change from the status quo in the IMF, including quota and voting share changes. In other words, unless the US voluntarily gives up its veto right, it will continue to dominate the IMF's formal governance. EU countries-by adding their voting shares altogether-also secured a veto right (IMF 2010b).

\subsection{Informal Decision-Making Power}

A state's informal decision-making power is determined by its capacity in influencing IMF policy decisions via IMF staff directly and/or through the Fund's informal forums and groups (Stone 2011: 55). First of all, all of the proposals to be approved by the EB are prepared by IMF staff as a product of rigorous fact investigation and data analysis. They would not submit a proposal knowing it is likely to fail; and the Fund's board meeting record did show that the EB rarely declined proposals (Martin 2006: 143). In this way, the IMF staff effectively run 'quality-controls' on the EB's policy decisions. The high proposal approval rate, or the successful 'quality control' in other words, is backed by the regular communication between IMF staff and the EDs offices. Secondly, a number of informal groups, such as the G7, the group of EU representatives to the IMF and the Asia Pacific Group, often actively engage in leveraging preferential access to IMF senior management and staff to affect the institutional agenda (Woods and Lombardi 2006; Lombardi 2011).

Although China's influence among IMF staff and in informal groups has increased rapidly since 1980, it yet lags behind the G7 countries. Among all the IMF members, the US has the largest capacity in influencing IMF staff's proposals and the Fund's agenda, either alone or through the G7. This is because the US has distinct institutional advantages over other countries, backed by its extensive diplomatic corps, influential private financial institutions, advantages in gathering information, and last but not least, the advantage of having the IMF located in Washington, DC (Stone 2011: 51-79). The rest of the G7 members often keep their voices consistent with the US. China, on the other hand, does not have any of the abovementioned advantages.

\section{China's Collaboration with the IMF}

When the Bretton Woods system was established in 1944, China was one of its initial founding members. Through this newly established international financial mechanism, the Kuomintang (KMT) government was eager to get access to external financial resources to help China solve balance of payments issues (Helleiner and Momani 2014: 50-58). The KMT government also believed that playing an important role in the IMF would enhance China's status in the international economy. These self-interested objectives coincided with those of the Communist Chinese government when it took over the representation of China in the IMF in 
1980. Beijing's take-over of China's IMF membership was motivated by a number of explicit goals (Jacobson and Oksenberg 1990):

- To learn methods and techniques of running a modern financial system that meet the international standards;

- To get information about foreign economies;

- To (re)-connect with foreign economic institutions via IMF programmes;

- To accelerate the expulsion of Taiwan from the international political society by demonstrating the People's Republic of China's legal membership in the IMF;

- To become a friendly member of the international political society to smoothen potential cooperation with foreign states.

Since then, China's goals regarding collaborating with the IMF have developed as its own interests in domestic economic development and its objectives in pursuing greater influence in global financial governance evolved. To fulfil the updated goals, the Chinese authorities have participated in a series of IMF programmes. As noted above, the Chinese government engages with the IMF based upon the Fund's functions in helping China meet its interests and objectives. Hence, this section discusses the China-IMF collaboration according to the IMF's functions, divided into two main categories 'IO specialization' and 'agenda setting power.' The collaboration in the latter category particularly reveals how China pursues leadership in global monetary governance through the IMF.

\subsection{IO Specialization}

China engages with the IMF due to the latter's outstanding expertise, political skills, and resources to perform various tasks, which are characterized as 'IO specialization' by Hawkins et al. (2006: 15).

\subsubsection{Technical Assistance}

The IMF provides their member states with TA in a variety of areas, such as central banking, monetary policies, fiscal policies and administration, exchange rate policies and official statistics, to help them improve economic policy design and practices. Aiming to learn the advanced methods and techniques in the abovementioned areas that meet the international standards, the Chinese authorities make requests for the IMF's TA based upon their own government officials' updated needs (Jacobson and Oksenberg 1990; IMF 2009a). China has received a considerable amount of TA from the IMF since the 1980s via training courses in IMF institutes, visits by IMF experts to China, and periodical postings of Chinese officials in both IMF headquarters and its Beijing office. The Chinese officials learned from the IMF how to use internationally standardized methods to format and process financial data and policies. For example, up to the mid-1980s, China was using figures for net material product (NMP) to measure its economy, which excluded the service sector. Under the IMF and the World Bank's aid, China 
switched to gross domestic product (GDP) measurements, and consequently gave prominence to the service sector (IBRD 1983, 1985).

In 2000, the IMF and China co-established the Joint IMF-China Training Programme (CTP) to provide policy-oriented training in economics and the related operational fields for Chinese officials. The IMF and the People's Bank of China (PBC) jointly decide the course schedule for the Programme. Due to the rising popularity of IMF training courses among Chinese officials, the Fund and the PBC built a training centre specifically for Chinese officials in Dalian in 2004.

Among all the IMF departments, the IMF Institute for Capacity Development has organized the largest number of training courses in economic management under the CTP. It also organizes high-level seminars for China's economic policy makers together with the world leading experts. For example, the Institute organized a highlevel seminar in 2004 to facilitate dialogues between international analysts and key Chinese policy makers on China's then controversial exchange rate issues. The IMF Statistics Department is the Fund's second largest training provider for China. It has organized a considerable amount of training programmes for the officials from China's crucial economic institutions, including the PBC, the Ministry of Finance, the National Bureau of Statistics, the China Banking Regulatory Commission, and the State Administration of Foreign Exchange. The programmes covered macroeconomic statistics, balance of payments, fiscal reform, taxation, and budgetary and monetary operations (IMF 2009a: 7-17).

The successful collaboration between IMF staff and Chinese authorities in TA programmes is largely because they have had converging goals, that is to ensure that Chinese officials are able to learn the methods and techniques in financial governance that meet the IMF's standards. Moreover, the IMF's TA programmes do not directly impinge upon China's domestic economic policies, because they focus mostly on methodological issues instead of ideological and structural ones in the core of China's economic policy making (Ferdinand and Wang 2013: 901). The Chinese government can control the contents of TA training programmes and the extent to which the programmes can reach Chinese officials, so that they do not feel being intruded by the Fund.

\subsubsection{Surveillance and Policy Advice}

IMF surveillance and policy advice is designed to oversee the international monetary system and examine the member states' economic policies and provide them with constructive advice. It is one of the IMF's most conventional functions, thanks to the Fund staff's expertise in (macro-) economic policies and the Fund's authority in international financial governance. It is also one of the IMF's most controversial functions, as the IMF is often accused of providing 'one size fits all' prescriptions to its member countries. For example, some IMF advice was notoriously unhelpful during a number of emerging market crises in the 1990s (Chin 2010). China participates in the IMF's surveillance and policy advice programmes in order to get useful feedback about its own economic policies. To get useful information and keep IMF surveillance accountable, the Chinese authorities must 
sacrifice a certain level of (economic) sovereignty and submit data and information to the Fund.

IMF country surveillance, namely the annual Article IV Consultation, channels most of the IMF policy advice to the Chinese authorities. IMF policy advice has tackled some essential issues in the Chinese economy, such as the under-valuation of RMB exchange rate, lack of transparency in financial management, banking sector reforms, and China's internal imbalances. The Chinese authorities nevertheless have the ultimate right to decide whether or not they will accept IMF advice and how they want to implement the advice.

Several changes in China's exchange rate policies could be attributed to IMF advice, for example China took the IMF's advice to devalue the RMB by $15.8 \%$ to solve the balance of payments issues in the mid-1980s (Lardy 1992). Under the IMF's influences, China gradually loosened the control on currency convertibility (Feeney 1998; PBC 1996), and eventually complied with Article VIII of the IMF Articles of Agreement to make its currency freely convertible on the current account in 1996 (IMF 1996). In addition, a series of institutional reforms in China's financial sector, including the advancement of the central banking system and several changes in corporate governance and financial legislation, were largely compatible with the IMF's policy advice for China's economic modernization (Kent 2007; Lardy 1998, 1999).

However, the Chinese authorities did not willingly accept all IMF advice. For instance, they battled hard against the IMF on China's exchange rate issues in the second half of the 2000s. The drastic increase in China's trade and current account surplus in the mid-2000s made the US and other western economies alert of China's 'under-valued' RMB. The US Treasury forced the IMF to revise the bilateral surveillance guidelines to discipline China's 'problematic' exchange rate regimes (IMF 2007; Blustein 2013). The revision was approved by the EB as the '2007 Decision on Bilateral Surveillance.' Pressurized by the G7, especially the US, the IMF became increasingly critical toward China's monetary policies during the bilateral surveillance and pushed China to adjust the exchange rate of the RMB. They contended that the undervalued RMB reduced the scope for running a more proactive and independent monetary policy with higher real interest rates, and that it also created distortions in relative prices that undermined the government's efforts to raise household income and to develop the service sector (IMF 2006, 2010c, 2011a, 2012, 2013).

The Chinese authorities, however, rebutted the IMF's claims and insisted that the $\mathrm{RMB}$ and the foreign exchange market were close to equilibrium, despite conducting some very moderate RMB appreciations from 2006 onwards. China's resistance toward a substantial RMB appreciation was backed by strong domestic economic and political interests. Revaluing the RMB would severely harm China's manufacturing-based export industries, the main job providers for the country's large population (Xinhua 2010; Renminwang 2009), especially on top of the declining external demands during the global financial crisis. The Chinese authorities stated that the RMB was found undervalued because of the IMF's incorrect assessment based upon an uncertain forecast of the future current account and its failure to take a broader view on the path of the real exchange rate (IMF 
2011a: 19). Beijing rejected the IMF's 2007 Decision on Bilateral Surveillance and withdrew from the bilateral surveillance with the IMF between 2007 and 2008 (IMF 2007; Foot and Walter 2011). The IMF hereafter entered a historical-low relationship with China. Their relationship only started to improve after the crisis burst, when both the US and the IMF tuned down the criticism of China's exchange rate policies. ${ }^{2}$

But minor conflicts still exist in the surveillances. In the post-crisis era, the IMF encouraged the Chinese authorities to deepen domestic economic reforms and to transform its unsustainable investment-led growth model into one that was driven by domestic consumption (IMF 2012). The IMF's advice, although compatible with the core of the central Chinese government's 12th 5-year plan as well as the PBC's pro-reform preference, has not yet generated any substantial result. The strongest resistance came from a number of powerful domestic interest groups whose economic and political benefits were deeply embedded in the status quo (Walter 2014; Jiang 2014; Chin 2014). For instance, the provincial governments were reluctant to reduce investment, which served as the main driving force of GDP growth for three decades. Neither did they want to close down the large factories with excess capacity and face the risk of social unrest arising from job reductions. Moreover, the Chinese state-dominant banking sector evidently blocked several profound financial reforms (Freeman and Yuan 2011).

In summary, the example of China's resistance to the IMF's advice on revaluing the RMB in the second half of the 2000s indicated that the contrast between Chinese and IMF economic and political interests hindered the collaboration between the two. Moreover, even when the IMF's interests and objectives converged with those of the Chinese central government, in the case of deepening Chinese domestic economic reforms in the post-crisis era, the conflicted preferences of local Chinese authorities prevented the central government from engaging further with the economically liberal-minded IMF.

\subsection{Agenda-Setting Power}

States sometimes consult the IMF when they face difficulties in reaching an agreement on urgent and/or contentious issues on their own, as the IMF's 'agendasetting power' can help them find a negotiated equilibrium (Hawkins et al. 2006: 16). Thanks to its authority in multilateral governance, the IMF provides states with common policy space to solve issues and set agendas for the disputed issue areas. A resolution passed through the IMF is considered to be more credible than that reached unilaterally or bilaterally. And solving issues in a cooperative manner with the IMF's other members can help China improve its international reputation. Moreover, when China lacks the capability to resolve disputes with stronger opponents directly, it often attempts to seek the IMF's intervention to either resolve the disputes or alter the policy environment in favour of the weaker.

\footnotetext{
${ }^{2}$ Blustein (2013) told exhaustive stories about how the US designed the IMF's attack on China's exchange rate policies via the 2007 Decision on Bilateral Surveillance. The US however retreated quickly from the attack after the global financial crisis burst, as it realized China could be useful in helping the US release the pain from the crisis.
} 


\subsubsection{International Monetary Reforms-Diversifying the IMS and Expanding the $S D R$}

When the market expectation of the collapse of US dollar escalated after the 2008 crisis burst, the Chinese authorities became extraordinarily anxious about the safety of their enormous holdings of US dollar assets. The Chinese government repeatedly urged the US to protect the value of China's US dollar assets and guarantee the Chinese capital's access to US product markets, but its efforts failed to generate effective results. Although China's governmental and private US assets holders became increasingly frustrated with this situation, they could not simply dump their US assets, for multiple reasons. First of all, they held so many US dollar assets that an initial sell would send the market a worrying signal and trigger value drops in the remaining investment. Second, the emerging economies believed in 'self-insurance', and thus continued to accumulate US government securities, which were some of the safest options during the 2008 crisis. Third, according to the Bretton Woods II story, a country would accumulate foreign reserves along with its export oriented-growth (Dooley et al. 2003). Therefore, being a large exporter, China was motivated to keep its US dollar reserves high and the RMB exchange rate low. Moreover, China's powerful state owned enterprises and some domestic political elites had significantly benefited from the investment-led and export-dependent growth model, and were reluctant to move away from it (Vermeiren 2013; Schwartz 2009).

Helleiner (2014) quoted Susan Strange's argument about the 'structural power' of the US in the global political economy to explain why foreigners continued to support the dollar during the crisis. However, the Chinese were aware of the longterm risk of the 'dollar trap' and sought to free themselves without sacrificing their US dollar assets. Along with other BRICs countries, the Chinese authorities questioned the legitimacy and sustainability of the US dollar-dominated IMS and demanded reforms. China's then president Hu Jingtao advocated diversifying the IMS to include more currencies as the main international currencies at the 2008 G20 Washington Summit, which was regarded as China's first explicit assertion about international monetary reforms (Xinhua 2008). Confronted with the US structural power, China alone was unable to destabilize the 'US dollar-dominance'; and, therefore, it called on the IMF to intervene and set new agendas for the reformed IMS. Chinese officials urged the IMF to strengthen its surveillance on the major reserve currency issuer countries (Baston 2009: A10; IMFC 2013, 2014), especially the US, and to promote diversifying the IMS and disconnecting it from the US domestic economic conditions and political interests.

The highlight of China's attempts to undermine the US dollar came from the PBC governor Zhou Xiaochuan. In early 2009, he published an essay 'Reform the International Monetary System,' proposing to eliminate the influence of (US) sovereign interests in international liquidity management, to enlarge the use of the IMF's SDR as a super-sovereign reserve currency and to add more currencies to the SDR basket (Zhou 2009). The last suggestion implied the PBC's attempt to push the RMB to join the SDR basket. Just a few months after Zhou's proposal, the IMF took a few moves to strengthen the SDR's role, including a general allocation and a 
special allocation of SDR 193 billion in total and an issuance of SDR-denominated bonds. (IMF 2009b)

China's advocacy for international monetary reforms received some immediate support from the international community, including other BRICs leaders, the Argentinean and French government, and some high-profile US economists including Joseph Stiglitz and Fred Bergsten. However, such support was soon overshadowed by both practical and political obstacles to the SDR. First of all, SDR expansion would be practically challenging, as the SDR —unlike the US Dollar-was not broadly issued and used in the private sectors and that the IMF lacked institutional resources to manage 'a super-sovereign reserve currency.' Some EDs in the IMF worried that regular SDR allocations would reduce reserve accumulation and cause moral hazard (IMF 2011b). Fund staff were not confident about the SDR's potential role in maintaining future international monetary stability (IMF 2011c). Second, Helleiner (2014) pointed out that the US agreed to the SDR allocations in 2009 as a 'cheaper' way-compared to IMF quota reforms - to boost IMF resources and buffer countries from balance of payments shocks. But in the long run, the US prevented fundamental reforms from happening in the IMS, as many powerful US multinational firms and its financial sector had gained massive benefits from the existing system. Chin (2014: 195-203) detailed how G7 countries, especially the US, successfully impeded China and other BRICs countries' pursuit of SDR expansion and international monetary reforms. Hence, although the Chinese officials continued to lobby for SDR expansion along with other international monetary reforms at the IMF and World Bank meetings in the following years, the popularity of the topic quickly declined. This shows that the US still had the dominant voice in the governance of international monetary affairs, whereas China lacked effective influences in the IMF to push forward substantial changes that might hurt the US interests.

\subsubsection{International Monetary Reforms-the RMB's Entry to the SDR Basket}

China's pursuit of international monetary reforms, however, reached a significant breakthrough. On 30 November 2015, IMF Executive Board decided to include the RMB in the SDR basket as the fifth currency next to the US dollar, the euro, the Japanese yen and the British pound, effective on 1 October 2016 (IMF 2015a). It was an important achievement for China's RMB internationalization strategy, accomplished together with the IMF. Being a SDR currency was expected to strengthen the RMB's international role without directly challenging the US dollar. Moreover, the RMB's entry to the SDR basket helped the PBC justify and enforce financial reforms against domestic resistances. In other words, the IMF helped the PBC set agendas for financial liberalization in China.

The IMF considered the possibility of adding the RMB to the SDR basket during the 2010 5-year SDR review, but the EB rejected the idea, as the RMB did not fulfil one of the two criteria for SDR currencies: being freely usable (IMF 2010d). In particular, a Fund report pointed out that adding a non-convertible currency such as 
the RMB to the SDR basket would 'reduce the attractiveness of the SDR' and 'lead the current SDR system to collapse' (IMF 2011c).

The EB nevertheless approved the RMB's entry to the SDR basket 5 years later following the Fund's 2015 5-year SDR review. The 2015 review specifically focused on whether the RMB was 'freely usable,' including (1) whether it was widely used to make payments for international transactions; and (2) whether it was widely traded in the principal exchange markets. The IMF staff team suggested in a report released in July 2015 that the RMB was exhibiting 'a significant degree of international use and trading' (IMF 2015b). The data in the report, however, showed that while the RMB's ranks for a number of indicators of the 'widely used' condition had risen rapidly since 2010, they had not only fallen far behind the existing SDR currencies but also failed to stand out among a number of 'secondtier' currencies including the Swiss Franc, Canadian Dollar and Australian dollar. The indicators of 'widely traded' condition showed even lower performance of the RMB. For example, the existing SDR currencies accounted for roughly $80 \%$ of the total foreign exchange turnover in 2013 while the RMB contributed merely $1.1 \%$ (IMF 2015b).

Despite the RMB's relatively small portion in international transactions and trades, this report instead emphasized the growing tendency of the RMB's international use across a range of instruments. The report acknowledged the RMB's achievement in the internationalization process while questioning the representativeness of the Fund's own indicators for the 'freely usable' criterion. In addition, the report also listed a few key operational requirements for the RMB to meet to join the basket, which provided the Chinese authorities (especially the PBC) with explicit guidelines for further work in the following months (IMF 2015b).

The Chinese authorities thus implemented a series of financial reforms to fulfil these operational requirements, which, however, triggered severe market fluctuations. The highlight of the reforms was that on 11 August 2015, the PBC announced a new mechanism to determine the daily reference exchange rate based on the previous day's closing onshore RMB rate, supply and demand conditions in the market and price movement of other major currencies (IMF 2015c; Xinhua 2015). The main purpose of the August reform was to include more market information and reduce government control in determining daily reference exchange rates, to meet the SDR basket entry requirement (Inman 2015). However, this change also forced the $\mathrm{PBC}$ to devalue the RMB, which evoked market concerns with growth prospects. The increasing expectation of RMB devaluation triggered large capital outflows in the following months (Xiao 2015). Noticing the market fluctuations in China, the IMF nevertheless suggested that the RMB was freely usable (IMF 2015c). Although the PBC's market-based exchange rate practices were not to be blamed solely for the fluctuations, the negative impacts of the August reform did show that the RMB was probably not truly ready for the SDR basket. If this was the case, why did the IMF bend its rules to add the RMB to the SDR basket?

Since China was the only strong SDR advocator, satisfying China's demand for letting the RMB join the SDR basket would strengthen the Fund's own influence in the IMS. Eswar Prasad, a former head of the IMF's China team commented that it was clever for the IMF staff to bend the rules to accept the RMB, by which the Fund 
could gain global legitimacy from giving a leading role to Beijing (Prasad quoted in Donnah and Anderlini 2015). Hence, the IMF's interests converged with those of China on this issue. In addition, lowering the criteria for SDR basket currencies to include the RMB enabled the IMF to balance between China and the US amid a number of disputed issues. On the one hand, China was frustrated with its disadvantaged position in a number of IMF related issues in the late 2000s and early 2010s. For example, the ratification of the 2010 IMF governance reform was severely delayed; the Chinese believed that the IMF attempted to lash out against China's exchange rate policies under the US instigation; and the IMF failed to divert the IMS away from its focus on the US dollar. Letting the RMB join the SDR basket thus served as a compromising solution to appease China's growing dissatisfaction with the IMF's inability to fulfil China's needs. On the other hand, the RMB's entry to the SDR basket would not challenge the US dollar's dominance in the IMS nor change the key operating rules of the current IMS in the short run (Zhang 2015; Bernanke 2015). Therefore, it was an appropriate move for the IMF to make facing the strong US influence in the Fund.

\section{Conclusion}

To conclude, when the Chinese authorities and the IMF have converging interests and objectives, in the cases of TA programmes and the RMB's entry to the SDR basket, their collaboration tend to generate satisfying results for both sides. However, if China's interests and objectives are incompatible with those of the IMF, the result of the collaboration is less satisfying to the Chinese. The dispute between the Chinese authorities and the IMF on China's exchange rate issues in the late 2000s was a good case in point. Even when the IMF's interests and objectives converged with those of Beijing, in the context of deepening Chinese domestic economic reforms in the post-crisis era, the conflicted preferences of local Chinese authorities prevented their central government from engaging further with the economically liberal-minded IMF.

In addition, China's relative influence in the IMF's institutional governance also largely impacts upon the result of China-IMF collaboration. China's influence in the IMF has increased along with its own economic power and its role in international financial affairs. This enabled China to engage more proactively in the IMF, for example to push for IMF governance reforms in favour of the Fund's emerging and developing economy members, to resist IMF advice that was perceived as harmful for the Chinese economy, to push the IMF to engage in IMS reforms, and to convince the IMF to add the RMB to the SDR basket. China's efforts were, however, hindered by its limited influence in the IMF's institutional governance, especially facing the mighty dominant power the US. Thanks to its strong influence in both the IMF's formal and informal governance, the US effectively forced the IMF to pass the 2007 decision on Bilateral Surveillance to discipline China's exchange rate policies; it blocked the ratification of the 2010 IMF governance reform; and it also prevented fundamental reforms from happening in the IMS despite China's requests. 
The results of China-IMF collaboration indicate that although China has gained larger influence in global monetary governance with the IMF's assistance in the past years, its effort toward leadership in the realm has encountered inevitable hurdles, especially those built by the US. As China's interests and objectives regarding key economic and political issues continue to grow, it will pursue further influence in global financial governance toward greater leadership. China's rapid outward expansion through trade and foreign investment, along with the rise of new IFIs such as the NDB and the AIIB, indicate Beijing's ambition and capacity in establishing an option outside the traditional international financial regime guided by the Bretton Woods System and centred around the US. While no evidence shows that China is ditching the existing option, as seen by China's increasing collaboration with the IMF (and the World Bank), the IMF does feel the urge to adjust its governance structure and policy practice to accommodate China's needs better, and thus keeping China on its side. The RMB's entry into the SDR basket is a good example of this emerging relationship between China and the IMF.

Open Access This article is distributed under the terms of the Creative Commons Attribution 4.0 International License (http://creativecommons.org/licenses/by/4.0/), which permits unrestricted use, distribution, and reproduction in any medium, provided you give appropriate credit to the original author(s) and the source, provide a link to the Creative Commons license, and indicate if changes were made.

\section{References}

Acharya, A. 2011. Asian Regional Institutions and the Possibilities for Socializing the Behaviour of States. ADB Working Paper Series on Regional Economic Integration, No. 82, Asia Development Bank.

Baston, A. 2009. The G-20 summit: China seeks more involvement—and more Clout—developed Nations watch Warily at Beijing, with Vast Foreign-Exchange Reserves, Upgrades Role in Global Affairs. The Wall Street Journal, 31 March, A10.

Bernanke, B. 2015. China's gold star. Ben Bernanke's blog on brookings. http://www.brookings.edu/ blogs/ben-bernanke/posts/2015/12/01-chinas-gold-star. Accessed 1 Dec 2015.

Blustein, P. 2013. Off balance: The travails of institutions that govern the global financial system. The Centre for International Governance Innovation.

Broz, J.L., and M.B. Hawes. 2006. US domestic politics and international monetary fund policy. In Delegation and agency in international organizations, ed. D. Hawkins, D. Lake, D. Nielson, and M. Tierney. Cambridge: Cambridge University Press.

Chin, G. 2010. Remaking the architecture: The emerging powers, self-insuring and regional insulation. International Affairs 86 (3): 693-715.

Chin, G. 2014. China's rising monetary power. In The great wall of money: Power and politics in China's international monetary relations, ed. E. Helleiner, and J. Kirshner. Ithaca: Cornell University Press.

Donnah, S., and Anderlini, J. 2015. IMF poised to admit China's renminbi in elite currency basket. Financial Times, 29 November 2015 http://www.ft.com/intl/cms/s/0/fd81211a-96a9-11e5-922887e603d47bdc.html\#axzz48GqVm2L2. Accessed 30 Nov 2015.

Dooley, M., Folkerts-Landau, D., and Garber, P. 2003. An essay on the revived Bretton Woods System, NBER Working Paper 9971, Cambridge, MA: National Bureau of Economic Research.

Feeney, W. 1998. China and multilateral economic institutions. In China and the World: Chinese foreign policy faces the new millennium, ed. S. Kim. Boulder: Westview Press.

Ferdinand, P., and J. Wang. 2013. China and the IMF: from Mimicry towards Pragmatic International Institutional Pluralism. International Affairs 89 (4): 895-910.

Foot, R., and A. Walter. 2011. China, the United States, and the global order. Cambridge: Cambridge University Press. 
Freeman, C., and Yuan, W. 2011. China's Exchange Rate Politics: Decoding he Cleavage Between the Chinese Ministry of Commerce and the People's Bank of China. Washington DC: Centre for Strategic and International Studies.

Han, S. 2007. Globalization and socialization in China. Global Economic Review: Perspectives on East Asian Economies and Industries 31 (2): 49-63.

Hawkins, D., D. Lake, D. Nielson, and M. Tierney. 2006. Delegation under anarchy: States, international organizations, and principal-agent theory. In Delegation and agency in international organizations, ed. D. Hawkins, D. Lake, D. Nielson, and M. Tierney. Cambridge: Cambridge University Press.

Helleiner, E. 2014. The status quo crisis. New York: Oxford University Press.

Helleiner, E., and B. Momani. 2014. The hidden history of China and the IMF. In The great wall of money: Power and politics in China's international monetary relations, ed. E. Helleiner, and J. Kirshner. Ithaca: Cornell University Press.

IBRD. 1983. China: Socialist economic development. IBRD: Washington, DC.

IBRD. 1985. China: Long-term Development issues and options. Washington, DC: IBRD.

IMF. 1996. People's Republic of China Accepts Article VIII. Obligations IMF Press Release No. 96/58, Washington, DC: IMF.

IMF. 2006. IMF Article IV Consultation for People's Republic of China. IMF Country Report No. 06/394, Washington, DC: IMF.

IMF. 2007. Review of the 1977 decision—proposal for a New decision. IMF: Public Information Notice, Washington, DC.

IMF. 2009a. Report on the technical assistance evaluation mission to the People's Republic of China. Washington, DC: IMF.

IMF. 2009b. IMF governors formally approve US\$250 Billion general SDR allocation. Press Release No. 09/283, Washington, DC: IMF.

IMF. 2010a. IMF executive board approves major overhaul of quotas and governance. IMF Press Release. Washington, DC: IMF.

IMF. 2010b. IMF Quota and governance reform-elements of an agreement. Washington, DC: IMF.

IMF. 2010c. IMF Article IV consultation for People's Republic of China. IMF Country Report No. 10/238, Washington, DC: IMF.

IMF. 2010d. IMF executive board completes the 2010 review of SDR valuation. Public Information Notice No. 10/149, Washington, DC: IMF.

IMF. 2011a. IMF Article IV consultation for People's Republic of China. IMF Country Report No. 11/192, Washington, DC: IMF.

IMF. 2011b. IMF executive board concludes the meeting on enhancing international monetary stabilitya role for the SDR? Public Information Notice No. 11/22, Washington, DC: IMF.

IMF. 2011c. Enhancing international monetary stability - a role for the SDR?. Washington, DC: IMF.

IMF. 2012. IMF Article IV Consultation for People's Republic of China. IMF Country Report No. 12/195, Washington, DC: IMF.

IMF. 2013. IMF Article IV Consultation for People's Republic of China. IMF Country Report No. 13/211, Washington, DC: IMF.

IMF. 2015a. IMF's executive board completes review of SDR basket, includes Chinese Renminbi. Press Release No. 15/540, Washington, DC: IMF.

IMF. 2015b. Review of the method of the valuation of the SDR-initial considerations. IMF Policy Paper. Washington, DC: IMF.

IMF. 2015c. Review of the method of valuation of the SDR, IMF policy paper. Washington, DC: IMF.

IMFC. 2013. Statement by Mr. Zhou Xiaochuan, Governor of People's Bank of China. Twenty-Seventh Meeting of the IMFC, Washington, DC: IMF.

IMFC. 2014. Statement by Mr. Yi Gang, Deputy Governor of the People's Bank of China. In TwentyNinth Meeting of the IMFC, Washington, DC: IMF.

Inman, P. 2015. Why has China devalued its currency and what impact will it have? Guardian, 11 August 2015 https://www.theguardian.com/business/2015/aug/11/china-devalues-yuan-against-us-dollarexplainer. Accessed 12 Aug 2015.

Jacobson, H., and M. Oksenberg. 1990. China's participation in the IMF, the World Bank, and GATT: Toward a global economic order. Ann Arbor: The University of Michigan Press.

Jiang, Y. 2014. The limits of China's monetary diplomacy. In The great wall of money: Power and politics in China's international monetary relations, ed. E. Helleiner, and J. Kirshner. Ithaca: Cornell University Press. 
Johnston, A. 2008. Social states: China in international institutions, 1980-2000. Princeton and Oxford: Princeton University Press.

Kent, A. 2002. China's international socialization: the role of international organizations. Global Governance 8 (3): 343-364.

Kent, A. 2007. Beyond compliance: China, international organizations, and global security. Redwood City: Stanford University Press.

Lardy, N. 1992. Foreign trade and economic reform in China 1978-1990. Cambridge: Cambridge University Press.

Lardy, N. 1998. China's unfinished economic revolution. Washington, DC: Brookings Institution Press.

Lardy, N. 1999. China and the international financial system. In China joins the World progress and prospects, ed. E. Economy, and M. Oksenberg. New York: Council on Foreign Relations Press.

Lombardi, D. 2011. The IMS through the Lens of Emerging Asia. In Asia and policymaking for the global economy, eds. K. Dervis, M. Kawai, and D. Lombardi. Tokyo: Asian development Bank Institute and Washington DC: The Brookings Institution.

Lynch, D. 2006. Rising China and Asian democratization: socialization to 'Global Culture' in the political transformations of Thailand, China, and Taiwan. Stanford: Stanford University Press.

Martin, L. 2006. Distribution, information, and delegation to international organizations: the case of IMF conditionality. In Delegation and agency in international organizations, ed. D. Hawkins, D. Lake, D. Nielson, and M. Tierney. Cambridge: Cambridge University Press.

Nielson, D., and M. Tierney. 2003. Delegating to international organizations: agency theory and World Bank environmental reform. International Organization 57 (2): 241-276.

Nielson, D., M. Tierney, and C. Weaver. 2006. Bridging the rationalist-constructivist divide: reengineering the culture of the World Bank. Journal of International Relations and Development 9: 107-139.

Park, S., and A. Vetterlein. 2010. Owning development: Creating policy norms in the IMF and the World Bank, eds. Cambridge: Cambridge University Press.

PBC. 1996. Regulations on the management of the settlement, sale, and purchase of foreign exchange. Beijing: People's Bank of China.

Renminwang. 2009. Wen Jiabao's response to wall street Journal Journalist's question: Any Country cannot pressure China on RMB revaluation and devaluation, 13 March 2009. http://lianghui2009. people.com.cn/GB/145749/8957879.html. Accessed 20 Feb 2012.

Schwartz, H. 2009. Subprime nation: American power, global capital, and the housing bubble. Ithaca: Cornell University Press.

Stone, R. 2011. Controlling institutions: international organizations and the global economy. Cambridge: Cambridge University Press.

Thacker, S. 1999. The high politics of IMF lending. World Politics 52 (1): 38-75.

Vermeiren, M. 2013. Foreign exchange accumulation and the entrapment of chinese monetary power: Towards a balanced growth regime? New Political Economy 18 (5): 680-714.

Walter, A. 2014. China's engagement with international macroeconomic policy surveillance. In The great wall of money: Power and politics in China's international monetary relations, ed. E. Helleiner, and J. Kirshner. Ithaca: Cornell University Press.

Woods, N., and D. Lombardi. 2006. Uneven patterns of governance: How developing Countries are represented in the IMF. Review of International Political Economy 13 (3): 480-515.

Xiao, L. (2015). "Xiao Lisheng Zhuanlan" cong 8.11 huigai lian renminbi huilv yu lilv dingjia jizhi ("Xiao Lisheng Column" Viewing $\mathrm{CNH}$ and interest rates mechanism from the 8.11 exchange rate reform). Reuters, 17 November 2015, Beijing. http://cn.reuters.com/article/column-yuan-reformidCNKCS0T60V520151117. Accessed 15 Dec 2015.

Xinhua. 2008. Hu Jingtao zai jingrong shichang he shijie jingji fenghui shang de jianghua (quanwen) (Hu Jingtao's Speech at the Summit on Financial Markets and the World Economy (full article)), 15 November 2008, Washington DC. http://news.xinhuanet.com/newscenter/2008-11/16/content_ 10364070.htm. Accessed 20 Feb 2013.

Xinhua. 2010. Wen Jiabao zai di liu jie zhongou gongshang fenghui shang de yanjiang (quanwen) (Wen Jiabao's Speech at the 6th EU-China Business Summit (Full Article)). 7 October 2010, Brussels. http://news.xinhuanet.com/politics/2010-10/07/c_12633528.htm. Accessed 20 Feb 2012.

Xinhua. 2015. China improves exchange rate formation system. 11 August 2015, Beijing, http://news. xinhuanet.com/english/2015-08/11/c_134503641.htm. Accessed 12 Aug 2015.

Zhang, M. 2015. Renminbi rulan you ruhe? Qing kan lutou xilie zhuanfang (The RMB enters the basket, so what? Interviews with the reuters). Fenghuang Zixun (Fenghuang Information), 1 December 
2015. http://inews.ifeng.com/yidian/46466796/news.shtml?ch=ref_zbs_ydzx_news. Accessed 1 Dec 2015.

Zhou, X. 2009. Reform the international monetary system. Essay by Dr. Zhou Xiaochuan, Governor of the People's Bank of China, 23 March 2009. http://www.pbc.gov.cn/publish/english/956/2009/ 20091229104425550619706/20091229104425550619706_html. Accessed 12 Oct 2012.

Jue Wang is Assistant Professor of Chinese Economy and International Political Economy in Leiden University Institute for Area Studies. She holds a Ph.D. in Politics and International Studies. She has conducted research and published on Chinese economic reforms, China's external economic relationship, China's role in global governance and emerging market economies. 